

\title{
The International Criminal Court and Israel's Acts in the Occupied Territories: Progress and Prospects
}

\author{
YÜCEL ACER \\ Ankara Yıldırım Beyazıt University, Turkey \\ ORCID No: 0000-0001-6542-7134
}

ABSTRACT Following the request of Palestine as a Party State to the Status of the International Criminal Court, the Prosecutor decided to start a preliminary investigation into the situation of Palestine. The preliminary investigation resulted in a request from the Prosecutor to the Pre-Trial Chamber I for clarification of the Court's jurisdiction in relation to the occupied territories of Palestine. Many significant issues concerning the status of Palestine as a State and its legal borders were raised during the preliminary investigation, both by the Prosecutor and during the examination of the Chamber. Although both the Prosecutor and the Chamber have approved that the Court has jurisdiction over the Palestinian territories, including those occupied by Israel, the prospect for the success of the trials by the Court depends on the cooperation of the international community as a whole and the State parties to the ICC Status.

Keywords: International Criminal Court, Jurisdiction, Israel, Occupied Territories of Palestine, War Crimes 


\section{Introduction}

O nce a part of the Ottoman Empire for four centuries, the Palestinian territories were placed under British Mandate ${ }^{1}$ through the mandate system of the League of Nations (LN) in 1920. According to Article 22 of the LN Statute, which was regarded as the mandates system's 'constitution, ${ }^{3}$ the mandatory powers were, on behalf of the League, to 'exercise' their 'tutelage' of "peoples not yet able to stand by themselves under the strenuous conditions of the modern world." 4

The British mandate was widely abused, with the permission of the UK and through the work of Zionist organizations, by allowing extensive Jewish migration to the Palestinian territories between 1922 and 1939. As a result, the Jewish population, which was around 56,000 at the beginning of the mandate, had risen to 608,000 by 1946 . The Jewish exodus eventually led to a Palestinian Arab resistance in the 1930s, which has continued ever since.

When Britain declared its intention to end the mandate and withdraw from the region immediately after WWII, and carried the issue to the United Nations (UN), a process of negotiation was carried out at the UN General Assembly. The proposal submitted to the General Assembly, known as the 'partition plan' of Palestine, was approved on November 29, 1947, as Resolution 181, with 33 affirmative votes, 13 against, and 10 abstentions. ${ }^{5}$

The non-binding resolution envisaged the establishment of an unnamed 'Arab State' and an unnamed 'Jewish State' in the Palestinian region. The decision essentially divided all Palestinian lands into eight regions, leaving three of them to the Arab State and three parts to the Jewish State. Jaffa, the seventh region, would be an Arab enclave within the Jewish area, and al-Quds was designated as a corpus separatum and placed under the international regime and the administration of the UN Trusteeship Council for a period of 10 years. ${ }^{6}$

It should be noted that the Resolution 181 contained important guarantees for the fundamental rights of individuals in the territories. These covered the right to free movement, freedom of religion, and all kinds of worship; no discrimination on the basis of race, religion, language, and gender; the right to equal protection by law, including family law; the right to respect for minority status, and the religious interests of individuals in language and culture; primary and secondary education for Arab and Jewish minorities; the right to run their own schools; the prohibition of confiscation of the personal property of Arabs in the Jewish State except for the public benefit.

Upon the declaration of the State of Israel on May 14, 1948, Arab-Israel clashes erupted immediately and ended in mid-1949 with a ceasefire agreement. ${ }^{7}$ The 
immediate actions of Israel focused on achieving certain political goals, especially concerning territory, in violation of Resolution 181. The lands accorded to the Jewish State by the decision were thus gradually expanded. The systematic violence against the Palestinian people caused them to seek refuge in neighboring states, resulting in the 'great Palestinian exodus.' In December 1948, the UN General Assembly adopted Resolution 194 (III), ${ }^{9}$ which demanded the Israeli evacuation of the occupied territories, and the return of the displaced.

In the following years, especially with the 1967 Arab-Israeli War, Israel occupied all of Palestine except the West Bank and the Gaza Strip. The UN resolutions taken in the following years demanded Israel's withdrawal from the occupied territories. Resolution 237, taken unanimously by the UN Security Council immediately following the 1967 War, states that "gaining a country through war" is unacceptable and that "Israel should withdraw from the occupied territories in the latest conflicts." ${ }^{10}$ Nonetheless, Israel continued to systematically violate the principles on the protection of fundamental human rights stipulated by both Resolution 181 and subsequent UN resolutions. ${ }^{11}$

It is a conscientious and legal defect that not all of these violations have so far been properly addressed in legal terms. Those responsible for illegal criminal acts have not been prosecuted, although the illegality of these acts has been registered since the very first UN General Assembly Resolution, 194 (III), on the dispute. In fact, similar acts continue at great speed. ${ }^{12}$

So far, only a small part of the issue, i.e., the wall that Israel started to build in the West Bank in 2002, was brought to the international judiciary, which resulted in a decision condemning the construction of the wall in many respects, such as the violations of the fundamental rights of individuals. ${ }^{13}$

Against this background of injustices, a legal process has recently been initiated before the International Criminal Court (ICC) to address the crimes and the criminals responsible for them. As a non-party State, the Government of Palestine issued a declaration on June 13, 2014, under Article 12(3) of the ICC Statue to accept the Court's jurisdiction over the alleged crimes committed "in the occupied Palestinian territory, including East al-Quds, since June 13, 2014." The State of Palestine later acceded to the Status of the ICC on January 2,2015 , by depositing its instrument of accession with the UN Secretary-Gen- 
The ICC Statute provides that the procedure concerning the trial and punishment of individuals could be done by acquiring the approval of the States eral. The ICC Statute entered into force for the State of Palestine on April 1, $2015 .^{14}$

Upon the request of the State of Palestine, the Persecutor initiated a preliminary examination on January 16, 2015, during the course of which the Prosecutor needed to make a request from

the Pre-Trial Chamber to decide on the scope of the territorial jurisdiction of the Court, referring especially to the occupied Palestinian Territories.

The Pre-Trial Chamber I delivered its decision on February 5, 2021. The decisions of both the Prosecutor and the Pre-Trial Chamber I have signified distinctive developments in the trial of those individuals responsible for crimes committed in the territory of Palestine. They have also addressed various issues concerning the status of Palestine as a State and occupied territories, as well as the prospective trial for the crimes committed in the Palestinian territories since 2015 . The review below addresses these significant matters as well as the prospect for the success of future trials.

\section{The Procedure before the ICC and the Referral of the Situation in Palestine}

As emphasized in the preamble and Article 1 of the ICC Statute, the Court was prepared to hold individuals responsible for certain crimes of international concern. The mandate of the Court is limited in terms of jurisdiction. The Court may not initiate its mandate unless these jurisdictional conditions are met.

\section{Initiation of an Investigation by the ICC}

An investigation on allegations concerning the commission of at least one of the crimes covered in Articles 5 to 8 of the ICC Statute can be initiated with certain procedures, which are defined in Article 13 of the Statute. A situation can be referred to by the Prosecutor of the ICC in three separate ways. A State party could refer a situation to the Prosecutor. ${ }^{15}$ Here, the party State or States should specify in the referral 'the relevant circumstances' with 'supporting documentation as far as possible. ${ }^{16}$ The second way is that under Chapter VII of the UN Charter, the UN Security Council may refer to the Prosecutor a situation in which one or more statutory crimes appears to have been committed. ${ }^{17}$ Third, the Prosecutor himself or herself may initiate an investigation proprio motu in respect to such crimes. In this way, the Prosecutor can receive information from all sources, including non-party States and non-State formations or individuals, to initiate an investigation on her or his own. ${ }^{18}$ 
In cases where the Prosecutor initiates an investigation proprio motu and concludes that "there is a reasonable basis to proceed with an investigation," the Prosecutor "shall submit to the Pre-Trial Chamber a request for authorization of an investigation." ${ }^{19}$ If the Pre-Trial Chamber considers that there is a reasonable basis to proceed with an investigation and that the case appears to fall within the jurisdiction of the Court, the Chamber shall authorize the commencement of an investigation. This is not the final decision on the commencement of the investigation, as the Court may decide in the later stages of the case that the Court lacks jurisdiction or that the case is not admissible. ${ }^{20}$ Similarly, if the Prosecutor concludes that the information provided does not constitute a reasonable basis for an investigation after the preliminary examination; he or she shall not initiate an investigation. Even if the decision is not affirmative, the Prosecutor may still consider further information as to the same situation in the light of new facts or evidence. ${ }^{21}$

As an international treaty, the Statute is open only to the participation of States, although the Court has jurisdiction over individuals rather than States. The ICC Statute provides that the procedure concerning the trial and punishment of individuals could be done by acquiring the approval of the States.

Therefore, if the Prosecutor initiates a proprio motu investigation, a Pre-Trial Chamber according to Article 15(4) of the Statute reviews the jurisdictional evaluation of the Prosecutor. In the event that a State party refers the situation, the Prosecutor may, but is not required to, request a decision from the PreTrial Chamber about 'jurisdiction' or 'admissibility' for clarification. In such cases, the Prosecutor may need a ruling from the Court concerning the question of jurisdiction or admissibility. ${ }^{22}$

\section{Referral of the Situation in Palestine}

Palestine acceded to the Status of the ICC on January 2, 2015, when it handed over its instrument of accession to the UN Secretary-General. The Statute entered into force for the State of Palestine on April 1, 2015. ${ }^{23}$

Before becoming a party to the ICC Statute, the Government of Palestine, then as a non-party State, had already issued a declaration under Article 12(3) of the Rome Statute, accepting the Court's jurisdiction over alleged crimes committed "in the occupied Palestinian territory, including East al-Quds, since June 13, 2014. The declaration requested the identification, persecution, and judgment of the authors and accomplices of the crimes within the jurisdiction of the Court." ${ }^{24}$

Following the referral by Palestine, the Prosecutor opened a preliminary examination on January 16, 2015, in accordance with Article 25(1)(c) of the Reg- 


\section{The fundamental aim of the preliminary examination was to determine whether the criteria of the ICC Statute concerning the issues of jurisdiction, admissibility and the interests of justice were met under Article 53(1) of the Rome Statute}

Forces (IDF) committed the war crimes. ${ }^{28}$ The Prosecutor has also concluded that the potential cases from an investigation of the alleged crimes would be admissible pursuant to the Statute. ${ }^{29}$ That is to say that any case which could be brought before the Court concerning the situation in occupied territories of Palestine would be admissible under the conditions of Article 17 of the ICC Statute, which focuses in paragraph 1(a) on the fact that the jurisdiction of the ICC is depended on the principle of complementarity to national jurisdiction.

Moreover, the crimes identified during a preliminary examination should be considered as illustrative only, ${ }^{30}$ and the Prosecutor would be able to expand or modify the investigation as the crimes allegedly continued to be committed. ${ }^{31}$

The jurisdiction of the ICC is justified if the competent national state is "unwilling or unable genuinely to carry out the investigation or prosecution." Article 17 further refers to the condition of gravity in paragraph $1(\mathrm{~d})$; therefore, by deciding that the potential cases would be acceptable, the Prosecutor actual meant that the competent States, i.e., Palestine and Israel, are either unwilling or unable to try those responsible and that the crimes seemed to be grave enough.

As the third criterion of opening an investigation, the Prosecutor noted that there were no substantial reasons to believe that "an investigation would not serve the interests of justice." 32 According to Article 53, paragraph 1(c) of the ICC Statute, to initiate an investigation, the Prosecutor should be satisfied that the alleged crimes are 'grave' and that the trials would serve the interests of the victims and justice.

Since the potential case was not initiated by the Prosecutor promo mouto, but was referred by a party State, the Prosecutor was not under obligation to seek authorization from the Pre-Trial Chamber to conduct an investigation. Although the Persecutor' Office decided that all the criteria to open an investigation into the situation were met, the Office did not consider this finding sufficient, but decided on January 22, 2020, to make a request of the Pre-Trial Chamber. The reason for this was "the unique and highly contested 
The fundamental question is whether Palestine is validly a State party to the ICC, in whose territories the crimes committed by nationals of a non-party State, e.g., Israel, fall under the jurisdiction of the Court legal and factual issues attaching to this situation, namely, the territory within which the investigation may be conducted."33

The decision of the Prosecutor has some important legal ramifications. The Prosecutor indicated that she based her acts on the fact that Palestine had been a State party to the Rome Statute since January 2, 2015, following the deposit of its instruments of accession pursuant to Article 125(3). ${ }^{34}$ Therefore, the primary position of the Prosecutor is that Palestine is a 'State' for the purpose of Article 12(2)(a), at least in terms of its status as an ICC State Party. ${ }^{35}$

However, the Prosecutor further noted that she was "mindful of the unique history and circumstances of the Occupied Palestinian Territory" and the fact that the question of Palestine's statehood under international law does not appear to have been definitively resolved. ${ }^{36}$ This means that the Prosecutor left the discussion over the issue of the statehood of Palestine as a distinct matter from the reviews within the criminal procedures of the ICC.

The Prosecutor still needed to make such a request because she needed to clarify, under Article 19(3) and under Article 12(2)(a) of the ICC Statute, the territorial scope of the Court's jurisdiction, especially due to the fact that certain parts of the territory of Palestine are under the occupation of Israel, a non-party State. The Prosecutor specified that she sought confirmation that the 'territory' over which the Court may exercise its jurisdiction, and which the Prosecutor might subject to investigation, comprised the West Bank, including East al- Quds and Gaza, and emphasized that such determination was made strictly for determining the Court's authority to exercise jurisdiction and its scope according to the Statute. ${ }^{37}$

The Prosecutor noted that it was necessary to have a ruling from the Pre-Trial Chamber pursuant to Article 19(3) of the Statute because it was necessary to ensure certainty on an issue likely to arise at a later stage of the proceedings, as well as to promote judicial economy and efficiency. ${ }^{38}$ In any case, any fundamental issues relating to jurisdiction should be settled before commencing an investigation. ${ }^{39}$

By this request, certain fundamental issues were not only addressed by the Prosecutor but also raised to be further reviewed by the Pre-Trial Chamber I. One of these issues is whether Palestine is a 'State', as only States have rights 
and obligations toward the ICC under that treaty. The second fundamental issue is, what exactly the legal borders of the State of Palestine are, as the scope of the territorial jurisdiction of the ICC is opened for detailed and further examination.

In addition to these fundamental issues, which essentially relate to the jurisdiction of the ICC, many more issues that have significant legal implications on future trials before the ICC were also reviewed before the Chamber, such as the status of the Oslo Accords, as will be seen below.

\section{Arguments and the Decision of the Pre-Trial Chamber I}

Upon a request of authorization to initiate an investigation by the Prosecutor, the Pre-Trial Chamber may or may not authorize an investigation, although this is subjected to subsequent determinations by the Court in relation to jurisdiction and admissibility. ${ }^{40}$ If the Pre-Trial Chamber refuses to authorize the investigation, this refusal shall not prevent the Prosecutor from presenting a new request, if the Prosecutor finds new facts or evidence about the situation in question. ${ }^{41}$

Before making its decision, the Pre-Trial Chamber I ${ }^{42}$ issued an order on January 28, 2020, ${ }^{43}$ to invite Palestine, Israel, interested States, and other States, organizations, and/or persons to submit written observations, and specified that all these observations must be confined to the matter of jurisdiction. The Chamber also found it necessary to appoint counsel from the Office of the Public Counsel for Victims in order to present the observations of the unrepresented victims.

The Chamber examined the Prosecutor's request on January 22, 2020, and with it the observations of groups of victims, and of 43 other States, organizations, and scholars who participated as amicus curiae. The Chamber's mandate to examine the request was due to Article 19(3) of the Rome Statute, which authorizes the Prosecutor to "seek a ruling from the Court regarding a question of jurisdiction or admissibility."

The Chamber noted that the issue of territorial jurisdiction would have to be further examined in the future, insofar as the Prosecutor may submit requests for the issuance of arrest warrants or summons.

The Chamber made its decision on February 5, 2021, over the request by majority, that the Court's territorial jurisdiction in the situation in Palestine, a State party to the ICC Rome Statute, extends to the territories occupied by Israel since 1967, namely Gaza and the West Bank, including East al-Quds. ${ }^{44}$ 


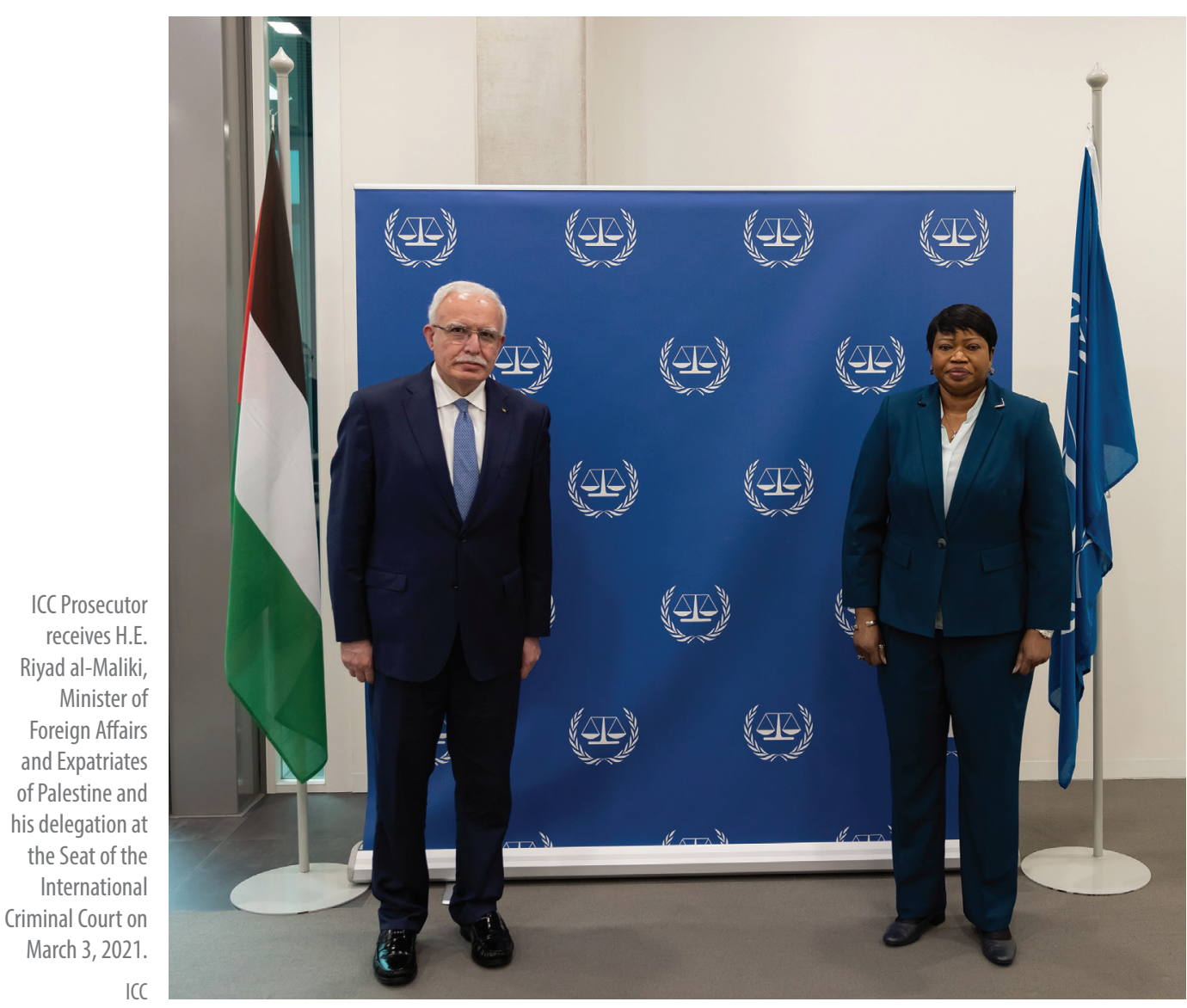

The decision was adopted by a majority of $2 / 3$. Judge Péter Kovács issued a partly dissenting opinion. His emphasis was that Palestine did not qualify as a State for the purposes of Article 12(2)(a) of the ICC Statute. ${ }^{45}$

\section{The Statehood of Palestine}

States that did not approve the ICC Statute have no obligations in relation to the ICC. Nevertheless, nationals of these non-party States may be subject to the Court's jurisdiction if they commit crimes in the territory of a party State. Another circumstance in which nationals of non-party States could be tried is the referral of a situation by the UN Security Council. ${ }^{46}$

Here, the fundamental question is whether Palestine is validly a State party to the ICC, in whose territories the crimes committed by nationals of a non-party State, e.g., Israel, fall under the jurisdiction of the Court. 


\section{Arguments of the Prosecutor}

Concerning the status of Palestine as a State, the Prosecutor argued that the Court should not make a separate assessment of the statehood of Palestine for exercising its jurisdiction in the territory of Palestine under 12(2). This is because the issue was already settled for becoming a party State when Palestine acceded to the Court. Accordingly, a State as pronounced in Articles 12(1) and 125(3), is a State under Article 12(2). ${ }^{47}$

The Prosecutor made an alternative submission to the Chamber concerning the status of Palestine as a State. According to this submission, the Chamber could likewise conclude for the strict purposes of the Statute that "Palestine is a State under relevant principles and rules of international law." ${ }^{48}$ In this regard, the Prosecutor pointed out that Palestine's restrictions in the exercise of its authority over the whole of the Occupied Palestinian Territory have to be assessed against the backdrop of the Palestinian people's right to self-determination. Since the exercise of the Palestinian people's right to self-determination was severely impaired by, inter alia, the imposition of certain unlawful measures, then this restriction should not be regarded as reasons to impair Palestine from the status of being a State. ${ }^{49}$

It is a significant observation because, the States that oppose to the status of Palestine as a State, including Israel, all depend on the restrictions of Palestine's jurisdiction over the occupied territories. The Prosecutor pointed out that since all these restrictions are in place because of the allegedly illegal acts, they cannot legally be taken to impair Palestine from the status of being a State.

\section{Israel's Arguments}

Israel argued that the ICC lacked jurisdiction over the 'situation in Palestine.' There were certain reasons Israel drew upon to argue as such. First, since Palestine does not have criminal jurisdiction over its territory and nationals, it cannot delegate such jurisdiction to the Court. ${ }^{50}$ Therefore, the accession by Palestine cannot itself provide a basis for the ICC's jurisdiction, as it did not settle the question of whether a sovereign Palestinian State exists. ${ }^{51}$

Israel raised some further 'justifications ${ }^{52}$ to assert that the Court lacked jurisdiction, as follows:

- General Assembly resolution 67/19 "did not purport to make a legal determination as to whether 'Palestine' qualifies as a State, and was explicitly limited in its effect to the UN." 
- Since the registry of the Palestinian accession by the UN Secretary-General as a depositary of multilateral treaties is not determinative of Palestinian statehood, this registration is not the endorsement of Palestine as a State,

- Similarly, the Palestinian participation in the Court's Assembly of States Parties cannot be taken to constitute or demonstrate such statehood because, "Palestine does not now possess, either in law or in fact, key elements of effective territorial control."

- Israeli-Palestinian agreements explicitly enumerate 'borders' among those issues to be settled 'through bilateral permanent status negotiations.' Therefore, "any exercise of territorial jurisdiction by the Court would not only require it to make a determination wholly unsuitable for an international criminal tribunal but would also contravene the agreements reached between the parties; and jeopardize efforts towards reconciliation."

- Terms such as 'the occupied Palestinian territory' cannot be relied upon, because the references to these terms are made in political terms rather than legal terms in relation to the question of sovereign title.

- Lastly, even if the Rome Statute were to be misinterpreted to allow non-sovereign entities to confer jurisdiction upon the Court, the latter would still be constitutionally constrained by the limits of delegation, and unable to exercise jurisdiction where the delegating entity has no jurisdiction to the extent required.

As summarized, Israel refused the exercise of jurisdiction by the Court in the Palestinian territory as a whole, basically arguing that Palestine is not a State and, even if it were, its jurisdiction is limited such that it is incapable of conferring jurisdiction to the ICC.

\section{Palestine's Arguments}

Quite contrary to Israel's position, Palestine argued that the ICC is fully competent to have jurisdiction over the territories of Palestine, including those occupied. The main arguments raised by Palestine to support this stance are as follows:

- First, Palestine avers that it "joined the Rome Statute as a State within its internationally recognized borders, as defined by the 1949 Armistice Line." ${ }^{53}$

- Second, Palestine added that the Statute gives no authority to the Court to make a determination on the issue of the statehood of a State party. ${ }^{54}$

- Palestine also argued that since the Statute reflects jus cogens prohibitions that prevail over any competing legal obligations, not of the same rank, any other regulations would be 'null' and 'void. 55

Consequently, Palestine argued that the Prosecutor's Office is fully competent to proceed to an investigation without seeking additional guidance from the Pre-Trial Chamber. ${ }^{56}$ 
The victims of the Israeli acts also submitted their arguments. They mostly argued that Palestine was a State for the purposes of Article 12(2) (a) and that the Court has territorial jurisdiction over Palestine. ${ }^{57}$ Therefore, the territory of Palestine is a place over which the Court may exercise its jurisdiction under Article 12(2)(a), covering the occupied Palestinian Territory (the occupied West Bank, including East al- Quds, and Gaza). ${ }^{58}$ It was noted that the endorsement of the instrument of accession of Palestine by the Secretary-General based on General Assembly Resolution 67/19 had resolved the question of Palestine's statehood in relation to acceding to the ICC Statute..$^{59}$

\section{Evaluations of the Chamber regarding the Question of Palestine's Statehood}

The Chamber observed that the core issue of its ruling concerned jurisdictional matter, which was actually the question raised by the Prosecutor under Article 19(3) of the Statute. ${ }^{60}$

The said Article provides that the Prosecutor's act to initiate an investigation or a prosecution may necessitate the resolution of a jurisdictional or admissibility question at an early stage of the proceedings. The decision to resolve these issues are to be given by the Pre-Trial Chamber at such an initial state. The Court may reconsider jurisdictional issues at later stages. ${ }^{61}$

The first point the Chamber emphasized is that the potential cases identified by the Prosecutor and the evolving investigation require the settlement of the question of jurisdiction. ${ }^{62}$ Therefore, the jurisdictional issues arising from Article 19(3) can be resolved during an investigation even before a single case emanates. $^{63}$

As to the core issue of the statehood of Palestine, the Chamber first determined whether Palestine could be considered a "State on the territory of which the conduct in question occurred" within the meaning of Article 12(2)(a) of the Statute, which refers to States party to the Statute. ${ }^{64}$

The Chamber stated that its handling of the issues was based primarily on the ICC Statute and secondly, Article 31(3)(c) of the Vienna Convention dealing with the interpretation of international conventions. ${ }^{65}$ 
The Chamber pointed out that the Statute does not provide a definition of a 'State, ${ }^{\prime 6}$ but rather refers to the term 'States Parties to this Statute' in Article 12(2). The same article does not clearly require the settlement of whether that entity has the necessary criteria to be a State under the relevant general rules of international law. ${ }^{67}$ The Chamber gave many examples from the Statute in which reference is made to 'State', such as $12(1), 119(2)$, and $125(3) .{ }^{68}$

The Chamber moreover emphasized that the Court is not empowered by the ICC Statute to decide on the issue of statehood. In fact, the creation to be a State under the relevant rules of international law is of a political character, which is irrelevant to the mandate of the ICC. ${ }^{69}$ Therefore, such a determination is out of the competence of the Court, which has an authority to rule on individual criminal responsibilities. ${ }^{70}$

According to the Chamber, whatever the legal status of Palestine as a State, its accession to the Statute is the result of an ordinary procedure prescribed by the ICC Charter. Once this process is complete in accordance with the relevant rules of the ICC Statute, the Court is left with no authority to review or challenge this act of accession, Consequently, Palestine is a party State of the ICC Statute, in relation to the requirements of Article 12(2)(a).

As seen clearly, the Chamber emphasized that the proper and successful conduct of the process of acceding to the Statute in accordance with Article 125(3) of the Statute was the significant element to consider Palestine as a party State. ${ }^{71}$ Palestine should therefore be treated as a State in relation to the Statute of the ICC. The Chamber also emphasized that no State party, except for Canada, manifestly opposed the accession of Palestine when the UN Secretary-General circulated Palestine's instrument of accession. ${ }^{72}$ Therefore, the Chamber pointed out that the submissions of States such as the Czech Republic, Austria, Australia, Hungary, Germany, Brazil, and Uganda, which raised objections to the consideration of Palestine as a State for the purposes of Article 12(2)(a) did not qualify as legally significant, as these States were silent at the time of the Palestinian accession. The fact that Palestine played an active role in the work of the Assembly of State Parties following its accession as a party State was also emphasized by the Chamber. ${ }^{73}$

Furthermore, Chamber maintained that Resolution 67/19 on December 4, 2012, decided by the United Nations General Assembly reaffirmed "the right of the Palestinian people to self-determination and to independence in their State." ${ }^{\prime 4}$ Therefore, Palestine would be able to become a party to any treaties that are open to 'any State' deposited with the Secretary-General.

Consequently, putting aside the issue of the statehood of Palestine under general international law, the Chamber approved that the accession of Palestine to 
the Statute as a party State is legally valid, as it properly followed the necessary procedure. ${ }^{75}$

\section{The Borders of the State of Palestine}

The Persecutor argued in the submission to the Chamber that "the Court's territorial jurisdiction extends to the Palestinian territory occupied by Israel during the Six-Day War in June 1967, namely the West Bank, including East al-Quds and Gaza." ${ }^{\text {76 }}$

There have been supporting views in the submissions to the Chamber that the territorial scope of the Court's jurisdiction is a legal question and falls within the Court's competence to determine notwithstanding any political ramifications. Others have argued that since the request by the Prosecutor concerns a political issue rather than a legal one, a possible ruling concerning the territory of Palestine would be a political decision, potentially affecting the legitimacy of the Court. ${ }^{77}$

The Chamber, however, expressed that it is competent to address this issue since the request of the Prosecutor covers issues within the Court's competence. According to the Chamber, since identifying the Palestinian territory for the purpose of the Court's jurisdictional scope is inevitably related to the question of Palestinian statehood, the decision of the Chamber would settle whether the accession process of Palestine as a State party was properly conducted. ${ }^{78}$ Furthermore, by determining the limits of the Court's territorial jurisdiction, the Chamber would not in fact adjudicate a dispute over the actual and future borders of Palestine. ${ }^{79}$

After affirming that the Chamber is competent to address the issue of the territorial scope of its jurisdiction, it moved on to examine whether the Court's jurisdiction extends to the Palestine territories occupied by Israel.

The first point the Chamber raised is that Resolution 67/19 of the UN General Assembly confirmed the Palestinian people's right to self-determination and independence as an independent State on the Palestinian territory occupied since $1967 .{ }^{80}$ The Chamber emphasized that bodies like the International Court of Justice (ICJ), the UN General Assembly, and the Security Council have approved the Palestinian people's right to self-determination within the occupied territories. ${ }^{81}$

According to the Chamber, the right to self-determination is at the same time an 'internationally recognized human right' within the meaning of Article 21(3) of 
One of the significant ramifications of the decisions of both the Prosecutor and the Pre-Trial Chamber is that certain acts committed in the territories of Palestine have been received as crimes, as defined by the ICC Statute the Statute. This article requires that the application and interpretation of the ICC Statute must be consistent with internationally recognized human rights. Therefore, as the UN General Assembly and the ICJ affirmed, this right must find its application also in the occupied territories of Palestine. ${ }^{82}$

The Chamber pointed out that a dispute over the borders of a State had never prevented an entity from becom-

ing a State party to the Statute. Such a dispute cannot accordingly preclude the Court from exercising its jurisdiction due to a dispute over borders. ${ }^{83}$

Third, the Chamber pointed out that the principle of territoriality is not the sole and absolute principle upon which States exercise their criminal law, and does not, therefore, coincide with territorial sovereignty. This means that any determination of the Court's territorial jurisdiction by the Chamber does not necessarily determine the scope of Palestine's territory. ${ }^{84}$ This is to say that the ruling by the Chamber on the territorial scope of its jurisdiction does not in fact address the border dispute under international law. ${ }^{85}$

The final point relates to the effect of the Oslo Accords on the jurisdiction of the Court. There was an argument at the stage of Preliminary Examination that Palestine could not delegate jurisdiction to the Court because Palestine does not have criminal jurisdiction with respect to Israelis or to crimes committed in Area C (nemo dat quod non habet), because the Oslo Accords of September 13, 1993 and September 28, 1995, provided as such. ${ }^{86}$

The Prosecutor refused this contention on the basis that the Oslo Accords did not preclude Palestine from joining in or acceding to the previous multilateral treaties. ${ }^{87}$ Therefore, there is no restriction by the Oslo Accords on the ability of Palestine to act internationally in this regard. ${ }^{88}$ The Oslo Accords, according to the Chamber, were not related to the Court's jurisdiction but rather to the issue of cooperation or complementarity during the stages of the investigation and prosecution.

The Chamber also looked at submissions from other State participants in this regard, ${ }^{89}$ and noted that the Israeli-Palestinian Interim Agreement on the West Bank and the Gaza Strip (Oslo II) contained some restrictions on the scope of the jurisdiction of the 'Palestinian Interim Self-Government Authority. ${ }^{\prime 90}$ However, the arguments regarding the Oslo Agreements in this context were not, according to the Chamber, relevant to the resolution of the Court's 


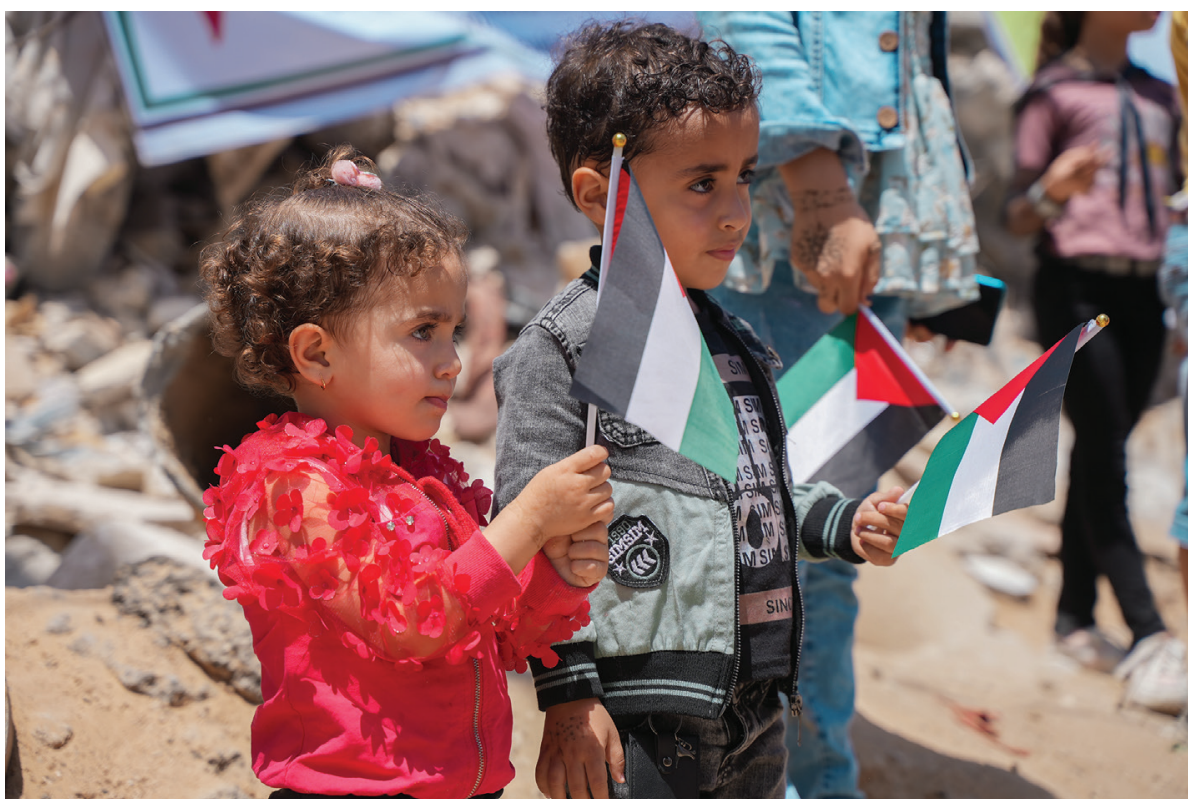

territorial jurisdiction in Palestine. The Chamber stated that the expressed views could be related to Article 19 of the Statute, but not to the question of jurisdiction in connection with the initiation of an investigation under Articles 13(a) and 14 of the Statute, i.e., initiation as a result of a referral by a State party. ${ }^{91}$

On the basis of these justifications, the Chamber concluded that the territorial jurisdiction of the Court covers the territories of Palestine occupied by Israel since 1967, including Gaza, the West Bank, and East al-Quds. ${ }^{92}$

\section{The Crimes in Question and the Prospects for Trials}

One of the significant ramifications of the decisions of both the Prosecutor and the Pre-Trial Chamber is that certain acts committed in the territories of Palestine have been received as crimes, as defined by the ICC Statute. The ICC Prosecutor emphasized that members of the Israeli Defense Forces (IDF) and Israeli authorities allegedly committed war crimes in the West Bank, including East al-Quds and the Gaza Strip. ${ }^{93}$

Especially during the 2014 clashes in Gaza, members of the IDF committed the following war crimes: intentionally launching disproportionate attacks in relation to at least three incidents on which the Office has focused; ${ }^{94}$ willful killing and willfully causing serious injury to body or health; ${ }^{95}$ and intention-
PFLP held a demonstration in solidarity with Palestinian families and children harmed by the Israeli bombardment, on the debris of buildings destroyed by Israeli attacks on al-Wahda Street in the city of Gaza, on May 25, 2021. 
ally directing an attack against objects or persons using the distinctive emblems specified by the Geneva Conventions. ${ }^{96}$

Based on the findings of the Prosecutor and the Pre-trial Chamber, it is clear that reasonable bases were identified to demonstrate that members of the Israeli authorities had committed war crimes under Article 8(2)(b)(viii) in relation, inter alia, to the transfer of Israeli civilians to the West Bank since June 13, 2014. The Prosecutor also concluded that any case that could potentially arise from the situation would be admissible according to Article 17(1)(a)-(d), which regulates the issue of admissibility. ${ }^{97}$

The concern of the Prosecutor was that the Prosecution had 'limited powers' at the preliminary examination stage, which had inevitably limited its findings at that stage. Due to this restriction, the Prosecution was unable to come to a determination on all the allegations. ${ }^{98}$ The limitation was due to the circumstances of the situation, especially in the West Bank, Gaza, and East al-Quds, occupied by Israel.

The Prosecutor explained that the crimes identified above were illustrative only. It is quite important to note that the Prosecutor's investigation in the future will not be limited to these crimes only, which were handled at the stage of the preliminary examination, and that the Prosecutor will conduct a more extensive investigation in the future. Moreover, the circumstances that led to crimes in Palestine continue, requiring continuous investigation. ${ }^{99}$

Eventually, the Prosecutor was satisfied with the Chamber's decision that the scope of the territorial jurisdiction of the ICC was clarified for the purpose of future prosecutions and trials. From now on, the Prosecutor will conduct extensive, independent investigations into the situation.

However, the remaining problem is whether the international community will give the necessary support to the Court. The Court needs cooperation, especially of the party States as well as the non-party States, and other relevant sources of information, to conduct an effective and successful investigation prosecution, trial, and enforcement of the sentences. Part 9 of the ICC Statue regulates international cooperation and judicial assistance.' Therefore, party States are put under a general obligation to "cooperate fully with the Court in its investigation and prosecution of crimes within the jurisdiction of the Court." 100

After receiving a State application, referral by the UN Security Council, or acting proprio motu to open an investigation, the Prosecutor will search for more information from various sources such as States, organs of the UN, intergovernmental or nongovernmental organizations, or other reliable sources. The Prosecutor can also receive written or oral submissions at the seat of the Court. ${ }^{101}$ 
As nobody can be tried in absentia and must be brought before the Court to be tried, ${ }^{102}$ the arrest and transfer of an accused inevitably necessitate the close and full cooperation of the related State parties, as the Court has no such authority and mechanism to arrest and transfer. The Prosecutor can request the presence of and question persons being investigated, as well as victims and witnesses, and seek the cooperation of any State or intergovernmental organization or arrangement. ${ }^{103}$ Moreover, after the initiation of an investigation, on the application of the Prosecutor, the Pre-Trial Chamber shall issue a warrant for the arrest of a person if the submitted evidence so requires. ${ }^{104}$

The Pre-Trial Chamber may authorize the Prosecutor to take specific investigative steps within the territory of a State party without having secured the cooperation of that State under Part 9 if the State is clearly unable to execute a request for cooperation due to the unavailability of any authority or any component of its judicial system competent to execute the request for cooperation under Part 9. ${ }^{105}$ In such cases, the cooperation and support of other states, especially those capable of providing the necessary support, is crucial.

Finally, the Court also needs the cooperation and support of the party States for the purpose of the enforcement of sentences of imprisonment. A sentence of imprisonment shall be served in a State designated by the Court from a list of States that have indicated to the Court their willingness to accept sentenced persons. ${ }^{106}$ Therefore, the willingness and effective enforcement measures of the appropriate States are quite significant, even for the execution of sentences.

The prospects for the investigation, trials, and enforcement of possible sentences in the situation in Palestine all depend on the effective cooperation of the international community in general and party States in particular. Although the Prosecutor decided to open an investigation upon the endorsement of Pre-trial Chamber I and announced that the investigation would cover crimes that are alleged to have been committed in the situation since June 13, 2014, the date to which reference is made in the Referral of the situation to the Prosecutor's Office, ${ }^{107}$ there are still some factors that cast a shadow over the investigation's future progress.

The fundamental obstacle is that many acts (and related evidence) that would fall within the competence of the Court have been and are being committed in 
the Palestinian territories occupied by Israel. The collection of evidence may well be obscured by Israel, which would inevitably create major obstacles for investigations and trials.

Second, most of the accused will be Israeli officials and citizens, as understood from the Prosecutor's submissions to the Pre-Trial Chamber concerning the above-mentioned crimes. The arrest of these persons and their transfer to the Court for trial will again be quite difficult due to Israel's possible preventive measures. It is also possible that the process could include the trials of members of Hamas and Palestinian armed groups. ${ }^{108}$

All of these factors demonstrate that the support of competent States, including non-party States, is crucial for the prospect of trials in the Palestinian case, especially the occupied territories of Gaze and the West Bank, including the East al-Quds. If a State party fails to comply with a request to cooperate by the Court, the Court may enter a finding to that effect and refer the matter to the Assembly of States Parties or, where the Security Council referred the matter to the Court, to the Security Council. As the Palestinian situation was not referred to the Court by the Security Council, the entire burden rests on the State parties and those non-party States that choose to support the Court in the situation in Palestine.

\section{Conclusion}

Following the declaration of the State of Israel in 1948, the first stage of an almost eight-decade-long period of the conflict emerged between the Palestinians and certain Arab countries on the one hand, and Israel on the other. During the course of the conflict, a significant amount of Palestinian territory has been occupied by Israel, as officially declared by many UN Security Council and General Assembly resolutions. These clashes, especially the attacks of Israel in the Palestinian territories, have been, and still are, violating the fundamental rights of Palestinians, most of which amount to criminal acts on the part of the perpetrators.

Although these perpetrators have so far escaped prosecution for many legal, political, and technical reasons, the ICC has recently started a process of criminal investigation following the request of the State of Palestine as a party State to the Status of the ICC. Many significant issues concerning the status of Palestine as a state and its borders were raised in relation to the scope of the jurisdiction of the Court during the preliminary investigation conducted by the Office of Prosecution. Following the decision of the Prosecutor, these issues were taken to Pre-Trial Chamber I by the Prosecutor for clarification of the scope of the Court's jurisdiction in terms of the territory of Palestine. 
Moreover, although neither the Prosecutor nor the Chamber have directly examined the issue of the statehood of Palestine and its legitimate borders, they have concluded that Palestine is a state party to the ICC Statute; and that the jurisdiction of the Court covers the occupied territories of Palestine, namely the West Bank, including East al-Quds, and the Gaza Strip.

Now the major concern is whether the investigation and the future trials by the Court over the acts committed in Palestine have a real prospect of being carried out. It is clear that the prospect depends on the cooperation and support of the State parties to the ICC as well as other States and organizations, as the Court does not have its own international mechanisms to collect the relevant evidence and capture those accused of committing the crimes, and bearing in mind that Israel could obscure such efforts of the Court, especially in the occupied territories.

One more criticism could be that the Prosecutor only refers to war crimes, which is only one of the four separate set of crimes enshrined in the ICC Statute. As there have always been illegal attacks and mass persecution of civilians during these attacks, crimes of aggression and crimes against humanity should also be taken into account during the prosecution and trials. As emphasized, the Prosecutor will definitely extend its investigation, and these sets of crimes will inevitably come and must come, into consideration.

Despite the uncertain future of the trials, the very fact that the crimes committed in the Palestinian territories are under criminal investigation is a major step toward fulfilling at least some requirements of justice.

\section{Endnotes}

1. The decision was taken at the San Remo Conference, a meeting of the Allied Supreme Council (Britain, France, Italy, and Japan) held on April 25, 1920.

2. For a review, see, Patrick C. R. Terry, "Britain in Palestine (1917-1948): Occupation, the Palestine Mandate, and International Law," University of Bologna Law Review, Vol. 2, No. 2 (January 2017), p. 190.

3. Terry, "Britain in Palestine," p. 215.

4. League of Nations Covenant, Article 22(1) and (2).

5. "Origins and Evolution of the Palestine Problem (Part I)," United Nations the Question of Palestine, retrieved July 18, 2021, from https://www.un.org/unispal/history2/origins-and-evolution-of-thepalestine-problem/part-i-1917-1947/\#Notes.

6. See, Resolution 181 (II), Future Government of Palestine,A/RES/181 (II).

7. "Origins and Evolution of the Palestine Problem," p. 33. For a review, see, Victor Kattan, From Coexistence to Conquest, International Law and the Origins of the Arab-Israeli Conflict, 1891-1949, (London, New York: Pluto Press, 2009), pp. 140-170.

8. "Origins and Evolution of the Palestine Problem," p. 33.

9. "Palestine - Progress Report of the United Nations Mediator A/RES/194 (II)," UN, UN General Assembly Resolution 194 (III), (December 11, 1948), retrieved from https://digitallibrary.un.org/record/210025.

10. Resolution 237 (1967) / [adopted by the Security Council at its $1361^{\text {st }}$ meeting], (June 14, 1967). 
11. See the next section, "The Crimes in Question and the Prospect for the Trials."

12. See the next section, "The Crimes in Question and the Prospect for the Trials."

13. "Legal Consequences of the Construction of a Wall in the Occupied Palestinian Territory," International Court of Justice, (2004), retrieved from https://www.icj-cij.org/en/case/131, p. 136.

14. "State of Palestine," International Criminal Court, (July 23, 2019), retrieved July, 20 2021, from https:// asp.icc-cpi.int/en_menus/asp/states\%20parties/asian\%20states/Pages/Palestine.aspx.

15. The ICC Statute, Article 13(a) and Article 14(1).

16. The ICC Statute, Article 14(2).

17. The ICC Statute, Article 13(b).

18. The ICC Statute, Article 15(2).

19. The ICC Statute, Article 15(3); Prosecution Request Pursuant to Article 19(3) for a Ruling on the Court's Territorial Jurisdiction in Palestine. ICC-01/18-12, (January 22, 2020), par. 2.

20. The ICC Statute, Article 15(4).

21. The ICC Statute, Article 15(6).

22. The ICC Statute, Article 19(3).

23. "State of Palestine," International Criminal Court.

24. "Declaration Accepting the Jurisdiction of International Criminal Court," International Criminal Court (December 31, 2014), retrieved from https://www.icc-cpi.int/iccdocs/PIDS/press/Palestine_A_12-3.pdf.

25. "The Prosecutor of the International Criminal Court, Mrs. Fatou Bensouda, Opens a Preliminary Examination of the Situation in Palestine," International Criminal Court, ICC-OTP-20150116-PR1083, (January 16, 2015), retrieved from https://www.icc-cpi.int/pages/item.aspx?name=pr1083.

26. "Situation in Palestine: Summary of Preliminary Examination Findings," International Criminal Court, (December 20, 2019), retrieved from https://www.icc-cpi.int/itemsDocuments/210303-office-of-the-prosecutor-palestine-summary-findings-eng.pdf.

27. "Prosecution Request," ICC-01/18-12, par. 94-96.

28. "Prosecution Request," ICC-01/18-12, par. 93-100; "Situation in Palestine: Summary of Preliminary Examination Findings," The Office of the Prosecutor, par. 2.

29. "Situation in Palestine," The Office of the Prosecutor, par. 4.

30. "Situation in Palestine," The Office of the Prosecutor, par. 7.

31. "Situation in Palestine," The Office of the Prosecutor, par. 9.

32. "Prosecution Request," ICC-01/18-12," par. 2.

33. "Statement of ICC Prosecutor, Fatou Bensouda, on the Conclusion of the Preliminary Examination of the Situation in Palestine, and Seeking a Ruling on the Scope of the Court's Territorial Jurisdiction," International Criminal Court, (December 20, 2019), retrieved from https://www.icc-cpi.int/Pages/item. aspx?name=20191220-otp-statement-palestine.

34. "Prosecution Request," ICC-01/18-12, par. 7.

35. "Prosecution Request," ICC-01/18-12, par. 56, 113.

36. "Prosecution Request," ICC-01/18-12, par. 5.

37. "Statement of ICC Prosecutor, Fatou Bensouda, on the Conclusion of the Preliminary Examination of the Situation in Palestine, and Seeking a Ruling on the Scope of the Court's Territorial Jurisdiction," International Criminal Court.

38. "Prosecution Request," ICC-01/18-12, par. 38.

39. "Statement of ICC Prosecutor, Fatou Bensouda, on the Conclusion of the Preliminary Examination of the Situation in Palestine, and Seeking a Ruling on the Scope of the Court's Territorial Jurisdiction," International Criminal Court. 
40. The ICC Statute, Article 15(4).

41. The ICC Statute, Article 15(5).

42. The Chamber was composed of Presiding Judge Péter Kovács, Judge Marc Perrin de Brichambaut, and Judge Reine Alapini-Gansou.

43. "ICC Pre-Trial Chamber Invites Palestine, Israel, Interested States and Others to Submit Observations," International Criminal Court, (January 28, 2020), retrieved July 18, 2021, from https://www.icc-cpi.int/ Pages/item.aspx?name=pr1512.

44. "Decision on the Prosecution Request Pursuant to Article 19(3) for a Ruling on the Court's Territorial Jurisdiction in Palestine," International Criminal Court, No. ICC-01/18, (February 5, 2021), retrieved from https://www.icc-cpi.int/Pages/record.aspx?docNo=ICC-01/18-143.

45. "Judge Péter Kovács' Partly Dissenting Opinion Public," ICC-01/18-143-Anx1 05-02-2021 1/163 EC PT.

46. See, the ICC Statute, Article 12 and 13.

47. "Prosecution Request," ICC-01/18-12, par. 7.

48. "Prosecution Request," ICC-01/18-12, par. 9.

49. "Prosecution Request," ICC-01/18-12, par. 9.

50. Israel, Office of the Attorney General, The International Criminal Court's Lack of Jurisdiction over the So-Called "Situation in Palestine,"(December 20, 2019), par. 2. See also par. 7-16; Israel, Ministry of Foreign Affairs, Office of the Legal Adviser, The International Criminal Court's Lack of Jurisdiction over the So-called "Situation in Palestine," Synopsis, December 20, 2019, par. 8.

51. Israel Attorney General Memorandum, par. 19; Israel Ministry of Foreign Affairs Memorandum, par. 14-15 and 19-20.

52. Israel Attorney General Memorandum, par. 19, 49. See also, par. 21-25; Israel Ministry of Foreign Affairs Memorandum, par. 16-18; 31-32, 55.

53. ICC-01/18-82, par. 28.

54. ICC-01/18-82, par. 10.

55. ICC-01/18-82, par. 68.

56. ICC-01/18-82, par. 9.

57. ICC-01/18-68, par. 19.

58. ICC-01/18-102, par. 55.

59. ICC-01/18-105, par. 2. See also, par. 12-20, 27-29.

60. "Decision on the Prosecution Request," No. ICC-01/18, par. 69.

61. “Decision on the Prosecution Request," No. ICC-01/18, par. 75.

62. "Decision on the Prosecution Request," par. 86.

63. "Decision on the Prosecution Request," No. ICC-01/18, par. 68.

64. "Decision on the Prosecution Request," No. ICC-01/18, par. 87.

65. "Decision on the Prosecution Request," No. ICC-01/18, 5 par. 88.

66. "Decision on the Prosecution Request," No. ICC-01/18, par. 92.

67. "Decision on the Prosecution Request," No. ICC-01/18, par. 93.

68. "Decision on the Prosecution Request," No. ICC-01/18, par. 95-98.

69. "Decision on the Prosecution Request," No. ICC-01/18, par. 54.

70. "Decision on the Prosecution Request," No. ICC-01/18, par. 106.

71. "Decision on the Prosecution Request," No. ICC-01/18, par. 100.

72. Depositary notification C.N.57.2015.TREATIES-XVIII.10. 
73. "Decision on the Prosecution Request," No. ICC-01/18, par. 100, 125, 129.

74. "Decision on the Prosecution Request," No. ICC-01/18, par. 98.

75. "Decision on the Prosecution Request," No. ICC-01/18, par. 102.

76. "Prosecution Request," ICC-01/18-12, par. 3.

77. “Decision on the Prosecution Request," No. ICC-01/18, par. 53, 125, 129.

78. “Decision on the Prosecution Request," No. ICC-01/18, par. 114, 125, 129.

79. “Decision on the Prosecution Request," No. ICC-01/18, par. 113, 125, 129.

80. United Nations, General Assembly, Status of Palestine in the United Nations, November 29, 2012, A/ RES/67/19, par. 116.

81. "Decision on the Prosecution Request," No. ICC-01/18, par. 118-122.

82. "Decision on the Prosecution Request," No. ICC-01/18, par. 122.

83. "Decision on the Prosecution Request," No. ICC-01/18, par. 115.

84. "Decision on the Prosecution Request," No. ICC-01/18, par. 62.

85. “Decision on the Prosecution Request," No. ICC-01/18, par. 113.

86. "Prosecution Request," ICC-01/18-12, par. 183.

87. "Decision on the Prosecution Request," No. ICC-01/18, par. 183-184.

88. "Prosecution Request," ICC-01/18-12, par. 184.

89. "Decision on the Prosecution Request," No. ICC-01/18, par. 124.

90. "Decision on the Prosecution Request," No. ICC-01/18, par. 125.

91. "Decision on the Prosecution Request," No. ICC-01/18, par. 129.

92. "Decision on the Prosecution Request," No. ICC-01/18, par. 118.

93. "Decision on the Prosecution Request," No. ICC-01/18, par. 94-96.

94. ICC Statute, Article 8(2)(b)(iv).

95. ICC Statute, Articles 8(2)(a)(i) and 8(2)(a)(iii), or Article 8(2)(c)(i).

96. See, ICC Statute, Article 8(2)(b)(xxiv), or 8(2)(e)(ii); "Prosecution Request," ICC-01/18-12, par. 93-100; "Situation in Palestine," The Office of the Prosecutor, par. 2.

97. "Situation in Palestine," The Office of the Prosecutor, par. 4.

98. "Situation in Palestine," The Office of the Prosecutor, par. 6.

99. "Situation in Palestine," The Office of the Prosecutor, par. 9.

100. The ICC Statute, Article 86.

101. The ICC Statute, Article 15(2).

102. The ICC Statute, Article 63(1).

103. The ICC Statute, Article 54(3)(b)(c).

104. The ICC Statute, Article 58(1).

105. The ICC Statute, Article 57(3)(d).

106. The ICC Statute, Article 103(1)(a).

107. "Statement of ICC Prosecutor, Fatou Bensouda, Respecting an Investigation of the Situation in Palestine," International Criminal Court.

108. The Prosecutor noted in her submission that members of Hamas and Palestinian armed groups have committed a number of crimes falling within the jurisdiction of the Court. "Prosecution Request," ICC-01/18-12, par. 100. 